\title{
CREATION OF PROMOTIONAL MATERIALS IN TRAVEL AGENCIES WITH FOCUS ON MODERN TOOLS OF MARKETING COMMUNICATION
}

\author{
[Tvorba propagačních materiálů v cestovních kancelárích se zaměřením na \\ moderní nástroje marketingové komunikace]
}

\author{
Lena Malačka ${ }^{1}$, Martin Přibyl ${ }^{2}$, Milan Křápek ${ }^{3}$ \\ ${ }^{1}$ Univerzita Tomáše Bati ve Zlíně, Fakulta managementu a ekonomiky, Mostní. 5139, 76000 Zlín \\ Email:malacka@fame.utb.cz \\ ${ }^{2}$ Soukromá vysoká škola ekonomická Znojmo s.r.o., Loucká 21, 66902 Znojmo \\ Email:pribyl@svse.cz \\ ${ }^{3}$ Soukromá vysoká škola ekonomická Znojmo s.r.o., Loucká 21, 66902 Znojmo \\ Email:krapek@svse.cz
}

\begin{abstract}
The article is looking for a suitable statistical model that would conclusively answered the question, how are travel agencies and vendor-agencies created promotional materials. Responses to this question were obtained using advanced statistical methods. The authors faced the problem of how suitable model, which would have an adequate audit trail, choose. Linear regression with artificial transformation was elected which included the partial indicators of the size of offices and agencies. Using this variable, then the question of whether there is a linear relationship between who form the materials and sizes of office.
\end{abstract}

Keywords: linear regression, promotion, promotional materials, research, travel agency, tourism.

JEL classification: M31

Doručeno redakci: 20.2.2017; Recenzováno: 6.3.2017; 10.3.2017; Schváleno k publikování: 31.5.2017

\section{Úvod}

Je nesporné, že v rámci každého tržního prostředí probíhá boj o zákazníka, přesněji nejen o zákazníka samotného a jeho nákup, ale také o jeho pozornost $\mathrm{v}$ době, kdy teprve dochází k nákupnímu rozhodování. Právě v těchto dvou fázích a současně v oblasti budování značky hraje významnou roli propagace jednotlivých konkurentů.

Příspěvek „Tvorba propagačních materiálů $\mathrm{v}$ cestovních kanceláríích se zaměřením na moderní nástroje marketingové komunikace“ zkoumá vztah způsobem, jak jsou tvořeny propagační materiály, které mají za cíl budovat značku, překonávat akviziční a prodejní mezeru (Karlíček a Král 2011) v kontextu moderních i tradičních marketingových nástrojủ. Šetření, které bylo provedeno kolektivem autorů, si klade za cíl odpovědět otázku, jakým způsobem jednotlivé podnikatelské subjekty přistupují $\mathrm{k}$ tvorbě komerčních sdělení $\mathrm{v}$ závislosti na velikosti subjektu (respektive počtu jeho zaměstnanců). Provedené šetření bylo zaměřeno i na další oblasti chování subjektů při propagování nabídky, tyto výsledky budou dále rozšířeny a analyzovány.

Šetření bylo zaměřeno na zaměstnance a vedení cestovních kanceláríi tak, aby získané informace vypovídaly o způsobu, jakým se rozhodují při tvorbě propagačních materiálů a jejich následném využití pro získání zákazníka. 


\section{Literární rešerše}

Vyšší podíl na využivání volného času učinil z cestovního ruchu jednu z hlavních ekonomických aktivit (Bouchet, Lebrun a Auvergne 2004). Z tohoto tvrzení by se mohlo zdát, že zde bude mít marketing vyšší potenciál než v jiných odvětvích. Často tomu však tak nebývalo (Morgan a Pritchard 1998). Jedním z hlavních důvodů bylo především to, že marketing se zde zaměřoval nikoliv na zákazníka, ale na destinace a jejich nabídku produktů (Williams 2012). Dř́ve totiž subjekty v cestovním ruchu používaly tradiční marketing, který byl realizován pomocí souboru strategií a implementace určitých nástrojů a metod. Nyní je ovšem nutné zvážit nové koncepty a prístupy, které budou zaměřeny na nové příležitosti vznikajícími v souvislosti s novými zákazníky. Tuto situaci však změnila především éra využívání internetu a technologií s ním spojených (Williams 2006).

Firmy, které realizují svou činnost především na internetu, využívají nejčastěji také internetovou reklamu, jako jeden ze způsobů propagace. V ČR je to dle výsledků Svatošové (2013) 66 \% firem obchodujících na internetu. Cestovní ruch a jeho odvětví se průběhu prvních desetiletí (1991 až 2002) staly lídrem ve využívání internetu, jelikož dokázaly velmi efektivně komunikovat se stávajícími i potenciálními zákazníky prostřednictvím online kanálů (Zach, Gretzel a Xiang 2010), přestože jejich činnost se stále odehrává také v kamenných pobočkách. Další fázi (od roku 2001 do současnosti) zaznamenal O'Connor (2008), kdy došlo k ještě významnějším změnám v marketingu cestovního ruchu. Technické zaměření webu se přesunulo $\mathrm{z}$ funkcionality a použitelnosti především na přesvědčení zákazníka, $\mathrm{k}$ čemuž v poslední době přispěla především také mobilní zařízení a později smartphony s neustále se zlepšujícími a sofistikovanějšími technologiemi zabudovanými uvnitř. GPS, fotoaparát nebo např. sociální sítě umožňují uživatelům ovládat jejich cestovatelské zkušenosti kdykoliv a odkudkoliv (Sigala, Gretzel a Christou 2012). Internet se tak stává preferovaným zdrojem informací o destinaci, při plánování cesty a rezervaci ubytování (Choi, Lehto a Oleary 2007). Xiang, Magnini a Fesenmaier (2015) ve svém výzkumu potvrdili, že internet a př́stup k němu přes mobilní zařízení dramaticky mění chování lidí při plánování cest - cestovatelé totiž nyní odkládají svá rozhodnutí, která dříve dělali před odjezdem.

Sociální média a další formy online komunikace vykazují enormní vliv na rozhodování spotřebitelů v cestovním ruchu. Sociální sítě jsou dle výzkumu Chlebovského a Plška (2012) v České republice aktivně využívány např. v oblasti ubytovacích a stravovacích služeb ve více jak $50 \%$ firem.

Velký vliv na návštěvníky v cestovním ruchu např. online recenze (Sotiriadis a Zyl 2013, Zhang et al. 2010). Důležité jsou nejen recenze př́mo na internetových stránkách hotelu, ale i na online stránkách cestovních agentur. Díky nim mohou kladné recenze významně zvýšit počet online hotelových rezervací učiněných přes webové stránky (Ye et al. 2011). Vermeulen a Seegers (2009) uvádějí, že velká část spotřebitelů v cestovním ruchu si před svým rozhodnutím čte recenze o destinacích a hotelech (např. na tripadvisor.com). Recenze neovlivňují spotřebitele jen v oblasti ubytovacích služeb, ale také v oblasti stravování, pozitivní názory spotřebitelů totiž zvyšují popularitu internetových stránek restaurací (Zhang et al. 2010). Stránky sociálních sítí a jejich obsah (fotografie, videa a komentáře pod nimi) se stávají čím dál populárnějšími při plánování výletů a cest (Xiang et al. 2015) a proto je mohou využít i destinace jako jeden z nástrojů ke zvýšení své konkurenceschopnosti (Királová a Pavlíčeka 2015).

Důležitou roli hraje v marketingové komunikaci cestovního ruchu také tzv. „eWOM“ (electronic word-of-mouth), který velmi souvisí s výše uvedenými recenzemi. WOM a doporučení od přátel a rodiny považuje za důvěryhodné médium $92 \%$ spotřebitelů na světě 
(Santos 2014). Dokáže totiž ovlivnit postoj spotřebitele, vnímání, záměry, ale také výběr produktu v kontextu plánování (Xiang et al. 2015).

Stále je velmi aktuální také problematika zasílání elektronických newsletterů. Komunikace pomocí newsletterů může $\mathrm{v}$ cestovním ruchu usnadnit začátek návštěvnické zkušenosti ještě ve fázi před návštěvou. Následně pak může sloužit jako nástroj $\mathrm{k}$,údržbě“ vztahů ve fázi postvisit (Leighann a Judith 2014). Klepek a Matušínská (2016) ovšem upozorňují na to, že např. pro skupinu obyvatel označovanou jako „singles“ je newsletter komunikačním kanálem, kterému nepřikládají př́lišný vliv.

V neposlední řadě je v cestovním ruchu využíván také mobilní marketing, díky němuž mohou subjekty cestovního ruchu přímo, rychleji a jednodušeji zasáhnout potenciálního zákazníka, urychlit postupy a zvýšit svou publicitu a povědomí (Selvi 2014). Mnoho spotřebitelů totiž nic neplánuje dopředu, ale odkládá důležitá rozhodnutí (hledání hotelu, restaurace, nákupních možností apod.) až se vydají na cestu (Xiang, Magnini a Fesenmaier 2015). Průzkum Pew Research Center ukazuje, že $23 \%$ americké dospělé populace používá svůj smartphone k vyhledání trasy nebo doporučení vztahujících se k aktuální poloze (Zickuhr a Smith 2011). Obdobně $30 \%$ Kanad'anů jsou v průběhu jejich cestování online (připojeni k internetu) a 64 \% těchto cestovatelů používá smartphony $\mathrm{k}$ př́stupu k online zdrojům (Ipsos 2011).

\section{Metodika}

V průběhu měsíce listopadu a prosince 2016 byl proveden průzkum mezi cestovními kancelářemi působícími v České republice. Celkem bylo osloveno všech 81 cestovních kanceláríi, které jsou členy Asociace cestovních kanceláŕí České republiky a zaměřují se na výjezdový cestovní ruch. Dotazování probíhalo elektronicky pomocí online platformy. Návratnost dotazníků byla 48,1 \%, odpovědělo tedy 39 cestovních kancelárín.

Průzkum byl zaměřen na identifikaci používaných nástrojů marketingové komunikace v cestovních kancelárích a dále především na způsoby tvorby a testování propagačních materiálů. Šetření se zaměřovalo na několik oblastí:

- kanály využívané k oslovení zákazníků,

- způsob zpracování propagačních materiálů (inhouse / dodavatelsky),

- softwarové nástroje využívané respondenty k tvorbě propagačních materiálů,

- způsoby testování vytvořených materiálů,

- využívání direct marketingových nástrojů,

- způsob reportování výsledků kampaní,

- hlavní cíle komunikačních aktivit.

Další z důležitých částí šetření bylo zjištění charakteristik cestovních kanceláří a agentur, ve kterých respondenti působí. Jednalo se zejména o:

- klíčové segmenty zákazníků,

- nejprodávanější produkt,

- a další identifikační charakteristiky (např́klad počet poboček a zaměstnanců, obrat, počet prodaných zájezdů).

V rámci statistického zpracování byly použity metody analýza závislostí, regresní analýza a dokazování parametrických hypotéz. Závislost i regresní křivka byla zvolena v lineárním tvaru. Následně pak byl ještě proveden dvouvýběrový t-test pro potvrzení zjištěných výsledků. 


\section{Výsledky průzkumu}

Pro potřeby článku bylo v průzkumu zjišt’ováno, jakým způsobem si cestovní kanceláře zpracovávají propagační materiály. $\mathrm{V}$ dotazníku bylo možné vybírat $\mathrm{z}$ následujících možností: „propagační materiály si zpracováváme sami“, ,jsou zpracovávány formou externí spolupráce“ a ,jsou zpracovávány najatou agenturou“. Jak je vidět v následující Tabulce 1 , z korelačních koeficientů je patrné, že čím větší je cestovní kancelář, tím větší je pravděpodobnost, že si nechává zpracovávat propagační materiály externím způsobem. Toto tvrzení platí v každém případě, at' je velikost měřena pomocí obratu, počtu zájezdů, poboček či zaměstnanců.

Tabulka 1: Korelační koeficienty, 5\% kritická hodnota (oboustranná) =0,2632

\begin{tabular}{|c|c|c|c|c|c|}
\hline obrat & zájezdů & poboček & zaměstnanců & materiály & \\
\hline 1,0000 & 0,9943 & 0,9891 & 0,9584 & 0,4296 & obrat \\
\hline & 1,0000 & 0,9877 & 0,9446 & 0,4212 & zájezdů \\
\hline & & 1,0000 & 0,9490 & 0,4174 & poboček \\
\hline & & & 1,0000 & 0,5308 & zaměstnanců \\
\hline & & & & 1,0000 & materiály \\
\hline
\end{tabular}

Zdroj: Vlastní práce

Pokud bychom určovali lineární regresi, pak bychom dostali následující výsledky. Všechny vysvětlující proměnné jsou navzájem lineárně závislé, je tedy předem jasné, že výsledný model bude obsahovat vysokou multikolinearitu. Z výsledků je ovšem možné určit, která z výše uvedených proměnných bude pro vysvětlování toho, kdo vytváří propagační materiály, nejvhodnější. Opět uvažujeme hladinu významnosti $\alpha=0,05$.

Tabulka 2: Výsledky lineární regrese pro všechny proměnné

\begin{tabular}{|c|c|c|c|c|}
\hline & Koeficient & Směr. chyba & $t$-podil & p-hodnota \\
\hline const & 1,63971 & 0,126149 & 12,9982 & $<0,0001$ \\
\hline Počet zájezdů & $9,21925 \mathrm{e}-06$ & $1,24975 \mathrm{e}-05$ & 0,7377 & 0,4641 \\
\hline Obrat & $9,00173 \mathrm{e}-010$ & $9,06169 \mathrm{e}-010$ & 0,9934 & 0,3252 \\
\hline Počet poboček & 0,0141314 & 0,0189875 & 0,7442 & 0,4601 \\
\hline Počet zaměstnanců & 0,0193906 & 0,0050848 & 3,8134 & 0,0004 \\
\hline $\begin{array}{l}\text { Střední hodnota závisle } \\
\text { proměnné }\end{array}$ & 2,107143 & $\begin{array}{l}\text { Sm. odchylka závisle } \\
\text { proměnné }\end{array}$ & 0,801784 & \\
\hline Součet čtverců reziduí & 22,30651 & Sm. chyba regrese & 0,661349 & \\
\hline Koeficient determinace & 0,369109 & $\begin{array}{l}\text { Adjustovaný } \\
\text { koeficient determinace }\end{array}$ & 0,319627 & \\
\hline
\end{tabular}

Zdroj: Vlastní zpracování

Z výše uvedené Tabulky 2 vyplývá, že nejvhodnější proměnnou pro vytvoření regresního modelu bude počet zaměstnanců, jehož p-hodnota je menší než hodnota alfa. Proto byly jednotlivé hodnoty přepočítány právě pro tuto proměnnou - počet zaměstnanců. Výsledky jsou znázorněny v Tabulce 3.

Koeficient determinace nově vytvořeného modelu (viz Tabulka 3) určuje, jak moc je možné se danou regresi spolehnout. V tomto př́padě je možné se na tento model spolehnout v $28 \%$. Abychom dokázali určit, jak moc změna počtu zaměstnanců ovlivní způsob tvorby propagačních materiálů, bylo by nutné studii provést na větším vzorku cestovních kancelárí. 
Tabulka 3: Výsledky lineární regrese pro proměnnou počet zaměstnanců

\begin{tabular}{|c|c|c|c|c|}
\hline & Koeficient & Směr. chyba & t-podil & p-hodnota \\
\hline const & 1,76943 & 0,11739 & 15,0732 & $<0,0001$ \\
\hline Počet zaměstnanců & 0,00662407 & 0,0014391 & 4,6029 & $<0,0001$ \\
\hline $\begin{array}{l}\text { Střední hodnota závisle } \\
\text { proměnné }\end{array}$ & 2,107143 & $\begin{array}{l}\text { Sm. odchylka závisle } \\
\text { proměnné }\end{array}$ & 0,801784 & \\
\hline Součet čtverců rezidúi & 25,39383 & Sm. chyba regrese & 0,685752 & \\
\hline Koeficient determinace & 0,281791 & $\begin{array}{l}\text { Adjustovaný koeficient } \\
\text { determinace }\end{array}$ & 0,268490 & \\
\hline
\end{tabular}

Výsledný model tedy lze popsat takto:

Propagační materiály $=1,76943+0,00662407 *$ počet zaměstnanců

Regresní model pak vypadá následovně, jak je znázorněno na Obrázku 1.

Obrázek 1: Regresní model

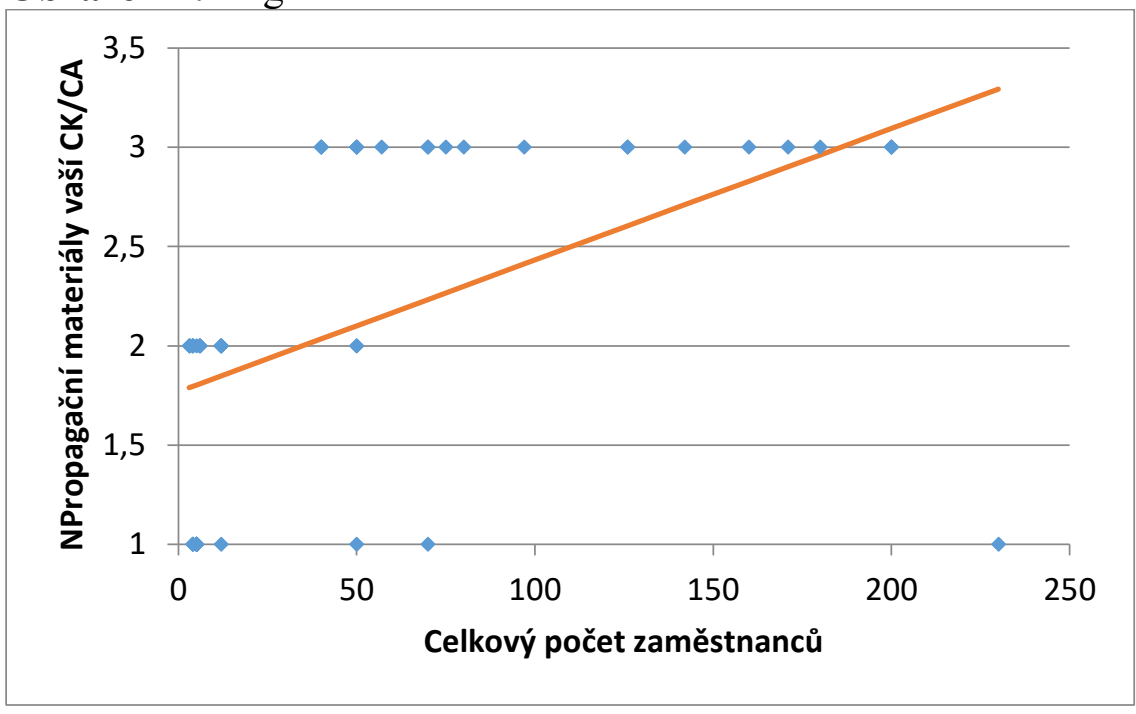

Zdroj: Vlastní zpracování

Výsledkem tedy je, že čím větší počet zaměstnanců cestovní kancelář má, tím více tíhne k tomu, aby jí materiály vytvářela externí agentura.

Vzhledem k nízkému koeficientu determinace, bylo třeba najít vhodnější model. Proto byla ze čtyř proměnných, které určují velikost $\mathrm{CK}$ každá z trochu jiného pohledu, vytvořena jedna, která kombinuje všechny čtyři proměnné a lépe určuje skutečnou velikost subjektu. Pokud bychom velikost určili tak, že seřadíme cestovní kanceláře dle všech čtyř proměnných, každé přiřadíme čtyři čísla, tak že nejmenší hodnotě je přiřazeno číslo 1 a největší číslo $n$, a tyto hodnoty následně sečteme, pak dostáváme proměnnou, která má tyto statistiky: stř̌ední hodnota $=107,50$, medián $=105,00$, minimum $=6,00$, maximum $=220,00$, směrodatná odchylka $=67,843$ a variační koeficient $=0,63110$. Pomocí této proměnné pak můžeme určit, zda existuje lineární závislost mezi tím, kdo tvoří materiály a velikostí kanceláře. Výsledná umělá proměnná a vysvětlovaná mají vyšší korelační koeficient, než ve všech předchozích př́padech. Lineární regrese dává v tomto případě také výrazně lepší výsledky (viz Tabulka $4 \mathrm{a}$ $5)$. 
Tabulka 4: Korelační koeficienty, 5\% kritická hodnota (oboustranná) = 0,2632

\begin{tabular}{|c|c|l|}
\hline velikost & materiály & \\
\hline 1,0000 & 0,6882 & velikost \\
\hline & 1,0000 & materiály \\
\hline
\end{tabular}

Zdroj: Vlastní zpracování

Koeficient determinace je v tomto př́ipadě téměř dvojnásobný oproti předchozím výpočtům.

Tabulka 5: Výsledky lineární regrese pro umělou proměnnou velikosti CK

\begin{tabular}{|c|c|c|c|c|}
\hline & Koeficient & Smër. chyba & t-podíl & p-hodnota \\
\hline const & 1,23279 & 0,147941 & 8,3330 & $<0,0001$ \\
\hline Velikost & 0,00813352 & 0,00116678 & 6,9709 & $<0,0001$ \\
\hline $\begin{array}{l}\text { Střední hodnota závisle } \\
\text { proměnné }\end{array}$ & 2,107143 & $\begin{array}{l}\text { Sm. odchylka závisle } \\
\text { proměnné }\end{array}$ & 0,801784 & \\
\hline Součet čtverců reziduí & 18,61023 & Sm. chyba regrese & 0,587055 & \\
\hline Koeficient determinace & 0,473650 & $\begin{array}{l}\text { Adjustovaný koeficient } \\
\text { determinace }\end{array}$ & 0,463903 & \\
\hline
\end{tabular}

Zdroj: Vlastní zpracování

Výsledný model tedy lze popsat takto:

Propagační materiály $=1,23279+0,00813352 *$ počet zaměstnanců

Přesnější výsledky jsou pak vidět i na následujícím Obrázku 2, kde velikost subjektu lépe odpovídá odhadované regresní křivce.

Obrázek 2: Regresní křrivka modelu s umělou proměnnou

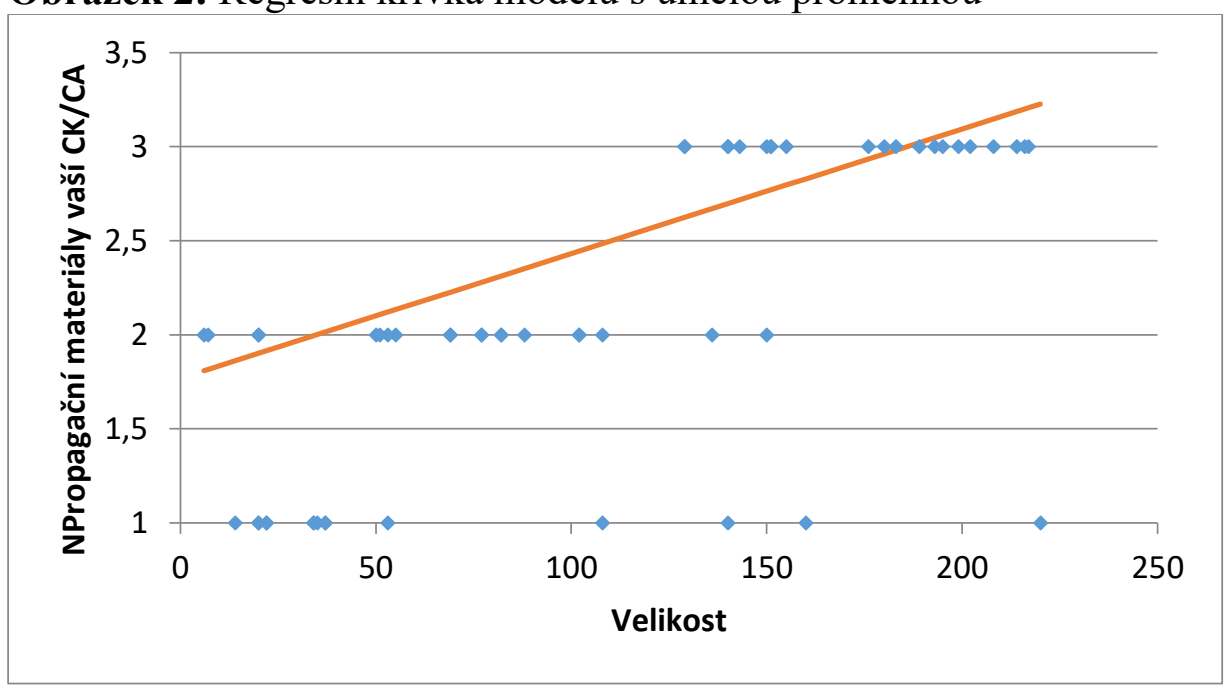

Zdroj: Vlastní zpracování

Dále se na tyto dvě proměnné podíváme ještě jiným způsobem a pro každý způsob zpracování propagační materiálů si určíme průměrnou velikost a směrodatnou odchylku velikostí, medián a další statistiky. Z Tabulky 6 je patrné, že kanceláře, které si zpracovávají materiály samy, mají průměrnou velikost 63,7 , ty co využívají externí pracovníky, mají průměrnou velikost 70 , ale jejich směrodatná odchylka je mnohem menší než u předchozích. Zatímco ty, které využívají služeb najaté agentury, mají průměrnou velikost 174,3, jsou tedy mnohem větší než ty předchozí. 
Tabulka 6: Popisná statistika

\begin{tabular}{|c|c|c|c|c|}
\hline Proměnná & $\begin{array}{c}\text { Střední } \\
\text { hodnota }\end{array}$ & Medián & Minimum & Maximum \\
\hline $\begin{array}{c}\text { Zpracováváme si } \\
\text { materiály sami }\end{array}$ & 63,7333 & 35,0000 & 14,0000 & 220,000 \\
\hline $\begin{array}{c}\text { Zpracovány formou } \\
\text { externí spolupráce }\end{array}$ & 70,2000 & 73,0000 & 6,00000 & 150,000 \\
\hline $\begin{array}{c}\text { Zpracovány najatou } \\
\text { agenturou }\end{array}$ & 174,286 & 180,000 & 129,000 & 217,000 \\
\hline celkem & 107,500 & 105,000 & 6,00000 & 220,000 \\
\hline Proměnná & Směr. odch & $\begin{array}{c}\text { variační } \\
\text { koeficient }\end{array}$ & Šikmost & $\begin{array}{c}\text { Stand. } \\
\text { špičatost }\end{array}$ \\
\hline $\begin{array}{c}\text { Zpracováváme si } \\
\text { materiály sami }\end{array}$ & 62,8961 & 0,986864 & 1,39276 & 0,631745 \\
\hline $\begin{array}{c}\text { Zpracovány formou } \\
\text { externí spolupráce }\end{array}$ & 39,2691 & 0,559389 & 0,113212 & $-0,446207$ \\
\hline $\begin{array}{c}\text { Zpracovány najatou } \\
\text { agenturou }\end{array}$ & 30,2012 & 0,173286 & $-0,0676610$ & $-1,44338$ \\
\hline celkem & 67,8434 & 0,631101 & 0,108243 & $-1,33222$ \\
\hline
\end{tabular}

Zdroj: Vlastní zpracování

Pokud chceme určit, zda se průměrné velikosti v jednotlivých kategoriích skutečně liší, provedeme sadu dvouvýběrových t-testů. Výsledné p-Hodnoty jsou uvedeny v Tabulce 7. Vidíme, že průměrná velikost kanceláří, které si zpracovávají materiály samy, nebo využivají externích pracovníků, se téměř neliší. Zatímco ty, které využívají agentury, jsou od zbylých dvou velmi odlišné a jsou průměrně mnohem větší než ty ostatní.

Tabulka 7: Výsledky dvouvýběrového t-testu

\begin{tabular}{|c|c|c|c|}
\hline p-value & $\begin{array}{c}\text { Zpracováváme si } \\
\text { materiály sami }\end{array}$ & $\begin{array}{c}\text { Zpracovány formou } \\
\text { externí spolupráce }\end{array}$ & $\begin{array}{c}\text { Zpracovány } \\
\text { najatou agenturou }\end{array}$ \\
\hline $\begin{array}{c}\text { Zpracováváme si } \\
\text { materiály sami }\end{array}$ & $\mathrm{X}$ & 0,7110 & 0,0000 \\
\hline $\begin{array}{c}\text { Zpracovány formou } \\
\text { externí spolupráce }\end{array}$ & & $\mathrm{X}$ & 0,0000 \\
\hline $\begin{array}{c}\text { Zpracovány najatou } \\
\text { agenturou }\end{array}$ & & $\mathrm{X}$ \\
\hline
\end{tabular}

Zdroj: Vlastní zpracování

Závěrem se tedy dá říct, že velikost cestovních kanceláří silně ovlivňuje to, kdo zpracovává jejich propagační materiály.

\section{Závěr}

Pro naplnění cílů šetření, které byly zmíněny v úvodních pasážích příspěvku, bylo nutné nalézt vhodný statistický model, který by průkazně odpověděl na otázku, jakým způsobem jsou v cestovních kancelářích a agenturách vytvářeny propagační materiály (varianty odpovědí: zpracovány najatou agenturou; zpracováváme si je sami (vlastními silami); zpracovány formou externí spolupráce).

Z výše uvedené Tabulky 2 vyplývá, že nejvhodnější proměnnou pro vytvoření regresního modelu bude počet zaměstnanců, jehož p-hodnota je menší než hodnota alfa. Proto byly jednotlivé hodnoty přepočítány právě pro tuto proměnnou - počet zaměstnancủ. 
Získaný koeficient determinace určil, jak moc je možné se danou regresi spolehnout. V tomto př́ipadě je možné se na tento model spolehnout v $28 \%$. Byl tedy hledán další, vhodnější model. Dalším krokem bylo vytvoření regresního modelu (viz Obrázek 1), ze kterého vyplynulo, že čím větší počet zaměstnanců cestovní kancelář má, tím více tíhne $\mathrm{k}$ tomu, aby jí materiály vytváŕela externí agentura. Vzhledem k nízkému koeficientu determinace, bylo třeba najít vhodnější model. Proto byla ze čtyř proměnných, které určují velikost CK každá z trochu jiného pohledu, vytvořena jedna, která kombinuje všechny čtyři proměnné a lépe určuje skutečnou velikost subjektu. Pomocí této umělé proměnné pak můžeme určit, zda existuje lineární závislost mezi tím, kdo tvoří materiály a velikostí kanceláře. Výsledná umělá proměnná a vysvětlovaná mají vyšší korelační koeficient, než ve všech předchozích případech. Lineární regrese dává $v$ tomto př́ípadě také výrazně lepší výsledky (viz. Tabulka 4 a 5). Byl vytvořen model, který je znázorněn na Obrázku 2, tedy modelu s umělou proměnnou. Výsledky modelu jsou prezentovány $\mathrm{v}$ Tabulce 6 , tedy podniky, které využívají externí pracovníky, mají průměrnou velikost 70 , zatímco ty, které využívají služeb najaté agentury, mají průměrnou velikost 174,3 , jsou tedy mnohem větší než ty předchozí.

Pro samotný dopad komunikačních aktivit cestovních kanceláŕí (a nejen jich) je třeba zmínit, že výsledky ovlivňují také další (a často významnější) faktory, jako např́íklad vhodné načasování sdělení, využití vhodného komunikačního kanálu, obsah samotného sdělení. $\mathrm{Na}$ druhou stranu prríspěvek odpovídá na otázku, kterou si klade vedení cestovní kanceláře při plánování komunikační strategie. Tedy, zda řešit propagaci in-house nebo externě. Závěrem se tedy dá říct, že velikost cestovních kanceláŕí silně ovlivňuje to, kdo zpracovává jejich propagační materiály. Získané výsledky jsou významné pro cestovní kanceláře $\mathrm{v}$ případě, že stojí před rozhodnutím, jakým způsobem dále vytvářet propagační materiály, nebot' vycházíme z předpokladu, že ostatní podniky (zastoupené respondenty) vyhodnocují propagační aktivity (jak bylo také zjištováno $\mathrm{v}$ rámci šetření) a volí pro ně nejvhodnější způsob tvorby propagačních prostředků. Získané výsledky představují pro subjekty, které se rozhodují o změně v rovině propagačních aktivit, odpověd', zda je $\mathrm{v}$ oboru cestovních kanceláŕí vhodnější využívat v jejich prŕípadě (v závislosti na velikosti podniku) služby externího dodavatele anebo řešit dané úkoly interně. $V$ př́padě, že se podnik rozhodne vydat jakoukoliv cestou, je vhodné předem nastavit vhodné klíčové ukazatele komunikačních aktivit a vymezit si dostatek prostoru na př́padné potřebné změny.

\section{Poděkování}

Tento článek vznikl za podpory grantu - "Využití nových marketingových trendů pro zvýšení výkonnosti firem ve vybraných oblastech ekonomiky" registrovaného u Interní grantové agentury FaME UTB IGA/FaME/2016/009 a „VGS 2016K01 Analýza vztahů a vazeb mezi podniky, zákazníky, veřejnou správou a občany“ registrovaného na Soukromé vysoké škole ekonomické Znojmo.

\section{Literatura}

[1] BOUCHET, P., A. M. LEBRUN and S. AUVERGNE, 2004. Sport Tourism Consumer Experiences: A Comprehensive Model.: A Comprehensive Model. Journal of Sport \& Tourism. Routledge, 9(2), 127-140. ISSN 14775085.

[2] CHLEBOVSKÝ, V. and V. PLŠEK, 2012. Research on Czech firms' marketing communication based on social media networks. Acta Univ. Agric. Silvic. Mendelianae Brun. Brno: Mendel University Press, 60(7), 111-118. ISSN 2464-8310.

[3] CHOI, S., X. Y. LEHTO and J. T. OLEARY, 2007. What does the consumer want from a DMO website? A study of US and Canadian tourists' perspectives. International Journal 
of Tourism Research. John Wiley \& Sons, Ltd, 9, 59-72. DOI: 10.1002/jtr.594. ISSN 15221970. Dostupné také z: http://dx.doi.org/10.1002/jtr.594

[4] IPSOS, 2011. The Ipsos Canadian inter@ctive Reid Report 2011 Fact Guide. Dostupné také http://www.ipsos.ca/common/dl/pdf/Ipsos_InteractiveReidReport_FactGuide_2011.pdf

[5] KARLÍČEK, M. a P. KRÁL, 2011. Marketingová komunikace: jak komunikovat na našem trhu. Praha: Grada. ISBN 978-80-247-3541-2.

[6] KIRÁL'OVÁ, A. and A. PAVLÍČEKA, 2015. Development of Social Media Strategies in Tourism Destination. Proceedings of the 3rd International Conference on Strategic Innovative Marketing (IC-SIM 2014). 175, 358-366. DOI: http://dx.doi.org/10.1016/j.sbspro.2015.01.1211. ISSN 18770428. Dostupné také z: http://www.sciencedirect.com/science/article/pii/S1877042815012719

[7] KLEPEK, M. and K. MATUŠÍNSKÁ, 2016. Purchasing Behaviour of Czech Singles and its Consequences on Marketing Communication Effectiveness. Acta academica karviniensia. Karviná: Slezská univerzita Obchodně podnikatelská fakulta v Karviné, (1), 57-69. ISSN 2533-7610. ISSN 2533-7610.

[8] LEIGHANN, N. and M. JUDITH, 2014. Using winery web sites to attract wine tourists: an international comparison: an international comparison. Intl Jnl of Wine Business Res. Emerald, 26, 2-26. DOI: 10.1108/IJWBR-07-2012-0022. ISSN 17511062. Dostupné také z: http://dx.doi.org.proxy.k.utb.cz/10.1108/IJWBR-07-2012-0022

[9] MORGAN, N. and A. PRITCHARD, 1998. Tourism promotion and power: creating images, creating identities. New York: Wiley. ISBN 04-719-8341-1.

[10] O'CONNOR, P., 2008. User-generated content and travel: A case study on Tripadvisor.com: A case study on Tripadvisor.com. Information and Communication Technologies in Tourism. 47-58. ISBN 9783211772799.

[11] SANTOS, S., 2014. 2012 \& 2013 Social Media and Tourism Industry Statistics. Dostupné také z: http://www.stikkymedia.com/blog/2012-2013-social-media-and-tourism-industrystatistics

[12] SELVI, M. S., 2014. Mobile Marketing Applications of Travel Agencies. International Journal of Research in Business and Social Science. Istanbul, Turkey: Society for the Study of Business and Finance, 3(4), 68-84. Dostupné také z: http://search.proquest.com.proxy.k.utb.cz/docview/1628558605?accountid=15518

[13] SIGALA, M., U. GRETZEL and E. CHRISTOU, 2012. Social Media in Travel, Tourism and Hospitality : Theory, Practice and Cases: Theory, Practice and Cases. Farnham, Surrey, Burlington, VT: Ashgate Pub.

[14] SOTIRIADIS, M. and C. ZYL, 2013. Electronic word-of-mouth and online reviews in tourism services: the use of twitter by tourists: the use of twitter by tourists. Electronic Commerce Research. Springer Science \& Business Media B.V, 13, 103-124. DOI: 10.1007/s10660-013-9108-1. ISSN 13895753.

[15] SVATOŠOVÁ, V., 2013. Význam internetové reklamy v elektronickém obchodování. Acta academica karviniensia. Karviná: Slezská univerzita Obchodně podnikatelská fakulta v Karviné, (4), 180-192. ISSN 2533-7610.

[16] VERMEULEN, I. E. and D. SEEGERS, 2009. Tried and tested: The impact of online hotel reviews on consumer consideration: The impact of online hotel reviews on consumer consideration. Tourism Management. Affiliation: Department of Communication Science, 
Faculty of Social Science, VU University, De Boelelaan 1081, 1081 HV Amsterdam, Netherlands; Correspondence Address: Vermeulen, I.E.; Department of Co, 30, 123-127. DOI: 10.1016/j.tourman.2008.04.008. ISSN 02615177. Dostupné také z: http://www.scopus.com/inward/record.url?eid=2-s2.0-

56649111315\&partnerID=40\&md5=12f64f507a2e37f5c505ebaca955889f

[17] WILLIAMS, A., 2012. Understanding the Hospitality Consumer. Oxford: ButterworthHeinemann, 288 p. ISBN 9781136351181.

[18] WILLIAMS, A., 2006. Tourism and hospitality marketing: fantasy, feeling and fun: fantasy, feeling and fun. International Journal of Contemporary Hospitality Management. Emerald, 18(6), 482-495. DOI: 10.1108/09596110610681520. ISSN 09596119. Dostupné také z: http://dx.doi.org/10.1108/09596110610681520

[19] XIANG, Z., V. P. MAGNINI and D. R. FESENMAIER, 2015. Information technology and consumer behavior in travel and tourism: Insights from travel planning using the internet: Insights from travel planning using the internet. Journal of Retailing and Consumer Services. 22, 244-249. DOI: http://dx.doi.org/10.1016/j.jretconser.2014.08.005. ISSN $09696989 . \quad$ Dostupné také z: http://www.sciencedirect.com/science/article/pii/S0969698914001131

[20] XIANG, Z. et al., 2015. Adapting to the Internet: Trends in Travelers' Use of the Web for Trip Planning: Trends in Travelers' Use of the Web for Trip Planning. Journal of Travel Research. THOUSAND OAKS; 2455 TELLER RD, THOUSAND OAKS, CA 91320 USA: SAGE PUBLICATIONS INC, 54, 511-527. DOI: 10.1177/0047287514522883. ISSN 00472875.

[21] YE, Q. et al., 2011. The influence of user-generated content on traveler behavior: An empirical investigation on the effects of e-word-of-mouth to hotel online bookings: An empirical investigation on the effects of e-word-of-mouth to hotel online bookings. Web 2.0 in Travel and Tourism: Empowering and Changing the Role of Travelers. 27, 634-639. DOI: http://dx.doi.org.proxy.k.utb.cz/10.1016/j.chb.2010.04.014. ISSN 07475632. Dostupné také http://www.sciencedirect.com.proxy.k.utb.cz/science/article/pii/S0747563210000907

[22] ZACH, F., U. GRETZEL and Z. XIANG, 2010. Innovation in the Web Marketing Programs of American Convention and Visitor Bureaus. Information Technology \& Tourism. 12, 47-63. ISSN 10983058.

[23] ZHANG, Z. et al., 2010. The impact of e-word-of-mouth on the online popularity of restaurants: A comparison of consumer reviews and editor reviews: A comparison of consumer reviews and editor reviews. International Journal of Hospitality Management. 29, 694-700. DOI: http://dx.doi.org.proxy.k.utb.cz/10.1016/j.ijhm.2010.02.002. ISSN 02784319. Dostupné také http://www.sciencedirect.com.proxy.k.utb.cz/science/article/pii/S0278431910000198

[24] ZICKUHR, K. and A. SMITH, 2011. 28\% of American adults use mobile and social location-based services. 2011. Dostupné také z: http://www.pewinternet.org/2011/09/06/28-of-american-adults-use-mobile-and-sociallocation-based-services/ 